\title{
PROFIL PENALARAN SISWA KELAS X SMA DALAM MENYELESAIKAN MASALAH PERSAMAAN KUADRAT DITINJAU DARI KEMAMPUAN AWAL SISWA
}

\author{
Rengga Mahendra ${ }^{1)}$, Wasilatul Murtafiah ${ }^{2)}$, Fatriya Adamura ${ }^{3)}$ \\ ${ }^{1}$ Pendidikan Matematika, FPMIPA, IKIP PGRI Madiun \\ renggamahendra69@gmail.com \\ ${ }^{2}$ Pendidikan Matematika, FPMIPA, IKIP PGRI Madiun \\ murtafiah.mathedu04@gmail.com \\ ${ }^{3}$ Pendidikan Matematika, FPMIPA, IKIP PGRI Madiun \\ fat3ya_adamura@yahoo.co.id
}

\begin{abstract}
Abstrak
Matematika merupakan salah satu mata pelajaran yang wajib ditempuh mulai dari tingkat dasar hingga ke jenjang yang lebih tinggi. Kesulitan siswa dalam pembelajaran matematika adalah terletak pada penalaran dalam menyelesaikan masalah bentuk soal cerita termasuk didalamnya pada materi persamaan kuadrat. Berdasarkan hal tersebut penelitian ini bertujuan untuk mengetahui profil penalaran siswa kelas X SMA dalam menyelesaikan masalah persamaan kuadrat ditinjau dari kemampuan awal siswa. Penelitian ini menggunakan pendekatan kualitatif dengan jenis penelitian deskriptif kualitatif. Sumber data yang digunakan pada penelitian ini adalah siswa. Teknik pengumpulan data melalui tes tulis dan wawancara. Analisis data dalam penelitian ini dilakukan dengan tahapan reduksi data, penyajian data, dan penarikan simpulan. Berdasarkan hasil penelitian diperoleh kesimpulan bahwa (1) Siswa dengan kategori kemampuan awal tinggi memiliki kecenderungan menggunakan unsur-unsur penalaran induktif dan deduktif dengan baik. Siswa dapat memecahkan masalah persamaan kuadrat dalam bentuk soal cerita dengan baik sesuai dengan langkah-langkah penyelesaian masalah. (2) Siswa dengan kategori kemampuan awal sedang memiliki kecenderungan menggunakan unsur-unsur penalaran induktif dan deduktif dengan cukup baik. Siswa dapat memecahkan masalah persamaan kuadrat dengan baik tetapi kurang mampu dalam menentukan cara lain untuk mencari jawaban. (3) Siswa dengan kategori kemampuan awal rendah memiliki kecenderungan menggunakan unsur-unsur penalaran induktif dan deduktif dengan kurang baik. Siswa kurang mampu dalam memecahkan masalah persamaan kuadrat sesuai langkahlangkah pemecahan masalah dan tidak mampu dalam menentukan cara lain untuk mencari jawaban.
\end{abstract}

Kata Kunci: Penalaran, Menyelesaikan Masalah, Persamaan Kuadrat, Kemampuan Awal

\section{PENDAHULUAN}

Pendidikan merupakan salah satu usaha untuk mengembangkan potensi sumber daya manusia menjadi lebih baik dan lebih unggul melalui kegiatan pembelajaran. Dengan adanya potensi sumber daya manusia yang mumpuni diharapkan kehidupan manusia dimasa yang akan datang bisa menjadi lebih baik. Potensi ini dapat digali dan dikembangkan secara efektif melalui strategi pembelajaran yang terarah dan terpadu, yang dikelola secara serasi, seimbang, dan terstruktur dengan memperhatikan pengembangan potensi siswa secara optimal. Salah satu pembelajaran yang dapat mengembangkan potensi sumber daya manusia menjadi lebih baik dan lebih unggul adalah melalui pembelajaran matematika. Dengan mempelajari matematika manusia akan terlatih untuk berfikir logis, kritis, dan sistematis.

Matematika merupakan salah satu ilmu dasar yang memegang peranan penting dalam penguasaan dan pengembangan ilmu pengetahuan dan teknologi. Cockroft (dalam Uno dan Umar, 2009: 108) berpendapat bahwa matematika sangat dibutuhkan dan berguna dalam keseharian, bagi sains, perdagangan, dan industri. Keberadaan matematika dianggap penting karena matematika adalah ilmu universal yang dapat diterapkan pada berbagai bidang ilmu pengetahuan yang lain. Dengan 
demikian, dengan adanya pembelajaran matematika diharapkan mampu menyiapkan sumber daya manusia yang berkualitas yang ditandai dengan memiliki kemampuan memperoleh dan mengelola informasi sesuai dengan tuntutan kebutuhan.

Matematika merupakan salah satu mata pelajaran yang wajib ditempuh mulai dari tingkat dasar hingga ke jenjang yang lebih tinggi. Tercapai atau tidaknya pendidikan dan pembelajaran matematika salah satunya dapat dilihat dari keberhasilan siswa dalam menerapkan konsep-konsep atau rumus-rumus matematika untuk menyelesaikan soal.

Berdasarkan hasil observasi yang dilakukan peneliti di MAN 2 Madiun kesulitan siswa dalam pembelajaran matematika adalah terletak pada penalaran dalam memecahkan masalah bentuk soal cerita termasuk didalamnya pada materi persamaan kuadrat. Selama ini siswa merasa bingung untuk memahami maksud yang terkandung dalam soal cerita dan kesulitan untuk menyatakan model matematika dari soal cerita tersebut. Ini sejalan dengan pendapat Wahyuni (dalam Marlina, 2013: 43-44) bahwa salah satu kesulitan yang banyak dialami siswa dalam pembelajaran matematika adalah menyelesaikan soal cerita. Kesulitan yang dialami siswa tidak hanya dalam memecahkan masalah yang menyangkut interpretasi suatu kalimat namun juga kesulitan dalam model matematika yang memiliki makna terkait dengan suatu masalah. Soal cerita merupakan soal matematika yang diungkapkan atau dinyatakan dengan kata-kata atau kalimatkalimat dalam bentuk cerita yang dikaitkan dengan kehidupan sehari-hari (Winarni dan Harmini, 2011: 122).

Kesulitan siswa dalam menyatakan model matematika dari soal cerita yang ada dikarenakan penalaran siswa yang tergolong masih rendah. Wahyudin (dalam Permana dan Sumarmo, 2007: 116) menyatakan bahwa hasil belajar matematika siswa selama ini masih belum menggembirakan khususnya dalam aspek penalaran, siswa kurang menggunakan nalar yang logis dalam menyelesaikan masalah matematika. Keraf (2010: 5) berpendapat bahwa penalaran adalah suatu proses berfikir yang berusaha menghubungkan fakta-fakta yang diketahui menuju pada suatu kesimpulan. Sedangkan menurut King (2012: 15) penalaran adalah aktivitas mental yang mengubah informasi untuk mencapai suatu kesimpulan. Jadi penalaran merupakan suatu proses yang sangat penting dan digunakan bagi siswa dalam memecahkan masalah matematika. Hal ini sesuai dengan pernyataan Nathaniel (dalam Ruslan dan Santoso, 2013:141) bahwa "Penalaran matematis yang diharapkan dari siswa adalah siswa mampu membuat keputusan tentang bagaimana cara mendekati permasalahan; menggunakan strategi, ketrampilan, dan konsep dalam menemukan solusi; menentukan solusi dengan lengkap dan urut dalam menyelesaikan masalah."

Tentu saja penalaran siswa dalam memecahkan masalah matematika dipengaruhi oleh beberapa faktor. Salah satu faktor yang mempengaruhi tingkat penalaran siswa adalah kemampuan awal siswa. Menurut Purwandari, Farida, Andista (2012: 85) kemampuan awal adalah pengetahuan, keterampilan, dan kemampuan yang telah dikuasai siswa untuk mempelajari tugas baru. Kemampuan awal merupakan prasyarat yang diperlukan untuk mengikuti pembelajaran materi berikutnya. Cepat lambatnya siswa dalam menguasai materi pelajaran matematika dipengaruhi oleh tingkat kemampuan awal siswa. Siswa yang mempunyai kemampuan awal tinggi atau sedang memungkinkan tidak mengalami kesulitan dalam memahami materi pelajaran matematika sehingga mempunyai prestasi belajar yang lebih baik, sedangkan untuk siswa yang mempunyai kemampuan awal rendah akan mengalami banyak kesulitan dalam memahami materi pelajaran matematika yang akan mengakibatkan rendahnya prestasi belajar matematika siswa (dalam Harun, 2010: 26). Dengan adanya kemampuan awal yang bagus diharapkan siswa akan lebih mudah dalam menyelesaikan permasalahan matematika yang diberikan.

Materi matematika dan penalaran matematika merupakan dua hal yang tidak dapat dipisahkan, yaitu materi matematika 
dipahami melalui penalaran, dan penalaran dilatihkan melalui belajar materi matematika, sehingga penalaran matematis sangat penting dan dibutuhkan dalam mempelajari materi matematika. Dengan demikian, dalam pembelajaran matematika hendaknya lebih ditekankan untuk mengembangkan potensi yang dimiliki siswa termasuk kemampuan bernalar, kreativitas, serta kemampuan dalam memecahkan masalah.

Berdasarkan uraian di atas, maka perlu diadakan penelitian yang bertujuan untuk mengetahui profil penalaran siswa kelas X SMA dalam menyelesaikan masalah persamaan kuadrat ditinjau dari kemampuan awal siswa.

\section{METODE PENELITIAN}

Pada penelitian ini menggunakan pendekatan kualitatif dengan jenis penelitian deskriptif untuk mengetahui profil penalaran siswa kelas X SMA dalam menyelesaikan masalah persamaan kuadrat ditinjau dari kemampuan awal siswa. Sugiyono (dalam Trianto, 2010: 179) mengatakan bahwa penelitian kualitatif adalah penelitian yang digunakan untuk meneliti pola kondisi objek alamiah di mana peneliti merupakan instrumen kunci. Penelitian kualitatif bersifat deskriptif analitis (Trianto, 2010: 180). Data yang diperoleh pada penelitian ini berupa lembar jawaban hasil pekerjaan siswa dalam memecahkan masalah persamaan kuadrat berdasarkan kemampuan awal siswa dan transkrip wawancara peneliti dengan subjek penelitian.

Sebelum melakukan penelitian, peneliti terlebih dahulu melakukan observasi dengan cara menanyakan kebenaran tingkatan prestasi belajar siswa kepada guru mata pelajaran matematika. Arikunto (dalam Gunawan, 2014: 143) berpendapat bahwa observasi merupakan suatu teknik pengumpulan data yang dilakukan dengan cara mengadakan penelitian secara teliti serta pencatatan secara sistematis. Peneliti selanjutnya menyiapkan uji soal prasyarat, instrumen penelitian, dan pedoman wawancara dengan terlebih dahulu dikonsultasikan dengan dosen pembimbing dan dilakukan validasi oleh validasi ahli yaitu guru mata pelajaran matematika sebelum diujikan kepada siswa. Uji soal prasyarat dilakukan guna untuk memperoleh subjek penelitian. Subjek dalam penelitian ini adalah 6 siswa kelas X MAN 2 Madiun yang dipilih berdasarkan kemampuan awal yang terdiri dari 2 siswa kategori kemampuan awal tinggi, 2 siswa kategori kemampuan awal sedang, dan 2 siswa kategori kemampuan awal rendah. Setelah diperoleh subjek penelitian, peneliti melakukan uji soal instrumen untuk mengetahui tingkat penalaran subjek dalam memecahkan masalah persamaan kuadrat yang dilanjutkan dengan sesi wawancara. Data yang diperoleh kemudian di validasi dengan menggunakan triangulasi metode dan di analisis dengan melakukan reduksi data, penyajian data, serta verifikasi data (Gunawan, 2014 : 210-211).

\section{HASIL DAN PEMBAHASAN}

Berdasarkan nilai tes soal prasyarat materi persamaan kuadrat, maka dipilih 6 subjek yang terdiri dari 2 siswa dengan kemampuan awal tinggi, 2 siswa dengan kemampuan awal sedang, dan 2 siswa dengan kemampuan awal rendah. Untuk selanjutnya akan disebut subjek I, subjek II, subjek III, subjek IV, subjek V, dan subjek VI. Adapun nilai tes soal prasyarat dapat dilihat pada Tabel 1:

Tabel 1 Daftar Nilai Subjek Penelitian

\begin{tabular}{ccc}
\hline $\begin{array}{c}\text { Subjek } \\
\text { No. }\end{array}$ & $\begin{array}{c}\text { Nilai Soal } \\
\text { Kemampuan } \\
\text { Awal Siswa }\end{array}$ & Kriteria \\
\hline 1 & 100 & Tinggi \\
\hline 2 & 90 & Tinggi \\
\hline 3 & 85 & Sedang \\
\hline 4 & 85 & Sedang \\
\hline 5 & 55 & Rendah \\
\hline 6 & 40 & Rendah \\
\hline
\end{tabular}

Berikut hasil penelitian menunjukkan profil penalaran siswa dalam memecahkan masalah persamaan kuadrat sebagai berikut: 


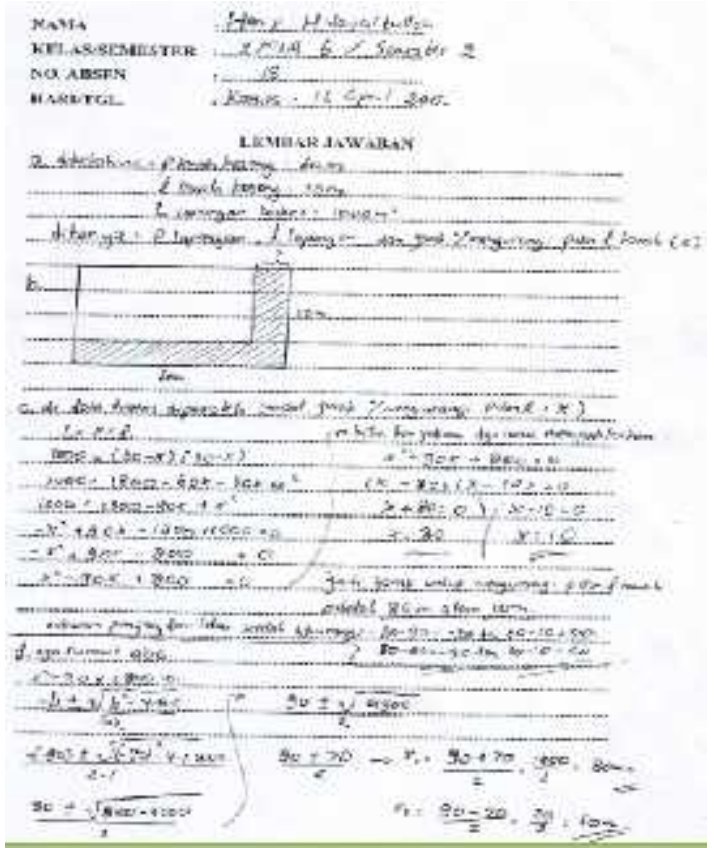

Gambar 1 Contoh Jawaban Subjek

Pada contoh jawaban subjek tersebut, peneliti dapat mengungkapkan 5 jenis penalaran yang digunakan subjek dalam memecahkan masalah persamaan kuadrat, adapun penjelasannya yaitu:

a. Penalaran Analogi

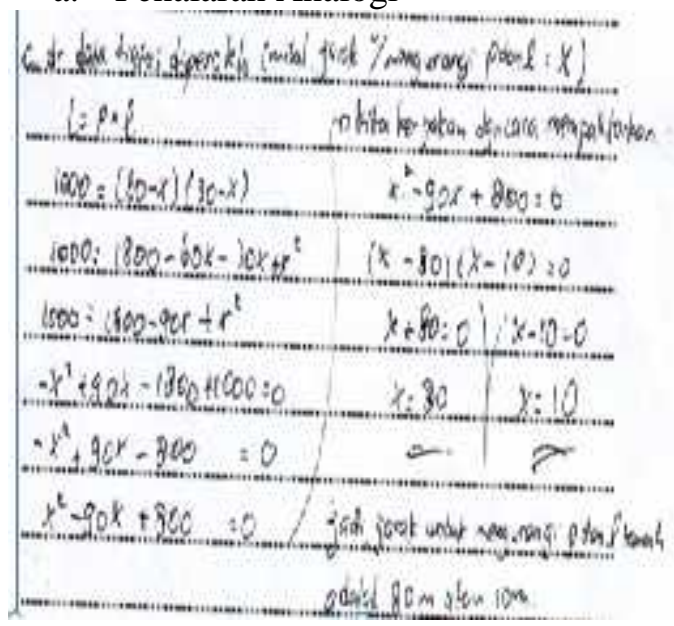

Gambar 2 Contoh Jawaban Subjek

Berdasarkan contoh jawaban subjek diatas maka dapat dilihat bahwa subjek mampu menyimpulkan apa yang berlaku bagi peristiwa yang satu akan berlaku juga bagi yang lain, ini terlihat dari subjek mampu membuat permisalan jarak pengurangan dimisalkan $x$, mampu menyebutkan yang diketahui dan yang ditanyakan dari soal, serta mampu menentukan hubungan antara yang diketahui dengan yang ditanya. Subjek dengan kemampuan awal tinggi, sedang, dan rendah mampu menggunakan penalaran analogi dalam menyelesaikan masalah persamaan kuadrat dengan baik.

b. Penalaran Klasifikasi

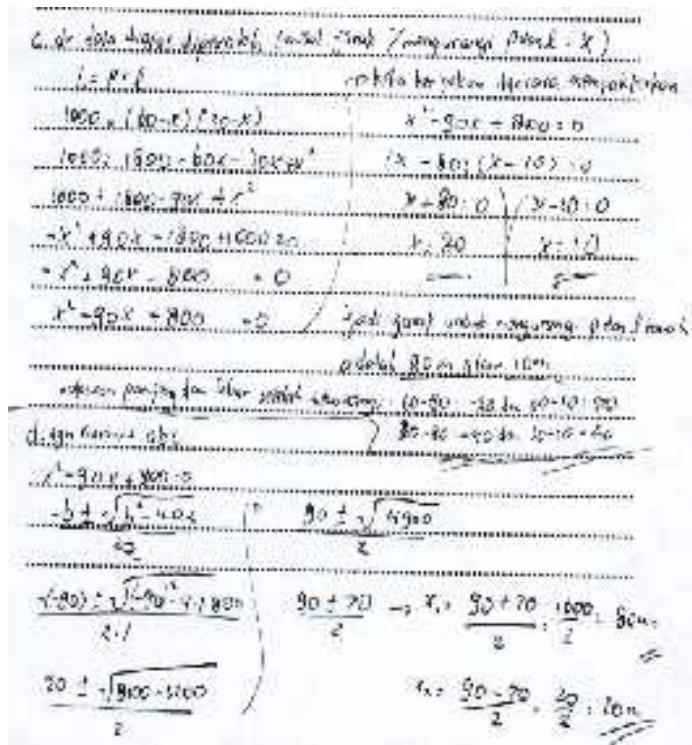

Gambar 3 Contoh Jawaban Subjek

Berdasarkan contoh jawaban subjek diatas maka dapat dilihat bahwa subjek mampu menarik kesimpulan dari contoh objek atau peristiwa khusus yang serupa, ini terlihat dari subjek mampu menggunakan cara lain dalam menentukan jawaban dari soal. Subjek dengan kemampuan awal tinggi mampu menggunakan penalaran klasifikasi dalam menyelesaikan masalah persamaan kuadrat dengan baik, sedangkan subjek dengan kemampuan awal sedang dan rendah kurang mampu menggunakan penalaran klasifikasi dalam menyelesaikan masalah persamaan kuadrat.

c. Penalaran Silogisme Kategorik 


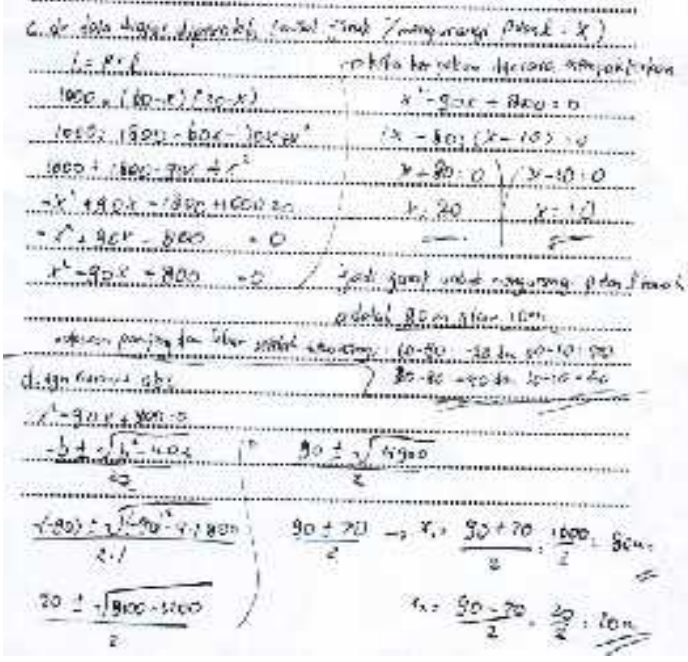

Gambar 4 Contoh Jawaban Subjek

Berdasarkan contoh jawaban subjek diatas maka dapat dilihat bahwa subjek mampu menarik kesimpulan dari hal yang khusus ke hal yang umum dengan menyebutkan tiga langkah penalaran yaitu: premis mayor ditunjukkan dengan menyebutkan rumus pada penyelesaian, premis minor dengan memberikan penyelesaian dari rumus yang digunakan kemudian mensubtitusikan hasilnya, dan kesimpulan ditunjukkan dengan menarik kesimpulan dari hasil penyelesaian, ini terlihat dari subjek mampu menentukan persamaan kuadrat dari yang diketahui, mampu menentukan akar-akar persamaan kuadrat, dan mampu mensubtitusikannya, serta menarik kesimpulan dari jawaban. Subjek dengan kemampuan awal tinggi dan sedang mampu menggunakan penalaran silogisme kategorik dalam menyelesaikan masalah persamaan kuadrat dengan cukup baik, sedangkan subjek dengan kemampuan awal rendah kurang mampu menggunakan penalaran silogisme kategorik dalam menyelesaikan masalah persamaan kuadrat.

d. Penalaran Silogisme Linier

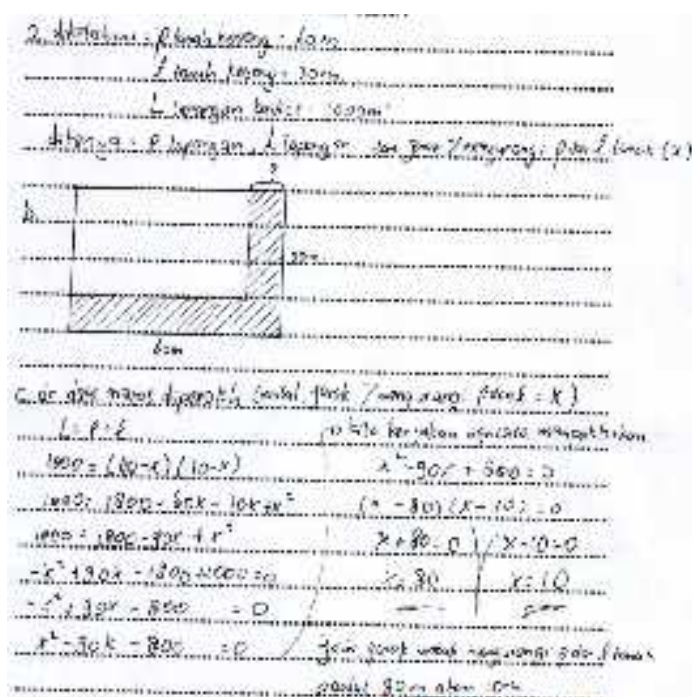

Gambar 5 Contoh Jawaban Subjek

Berdasarkan contoh jawaban subjek diatas maka dapat dilihat bahwa subjek mampu menyusun secara urut atau linier pada masingmasing objek yang dinyatakan di dalam premis-premis, yaitu subjek dapat menuliskan cara penyelesaian secara urut atau linier mulai dari menyatakan yang diketahui dan ditanyakan pada soal, membuat model matematika, hingga mengerjakan, dan mampu menentukan jawaban. Subjek dengan kemampuan awal tinggi, sedang, dan rendah mampu menggunakan penalaran silogisme linier dalam menyelesaikan masalah persamaan kuadrat dengan baik.

e. Penalaran Kondisional

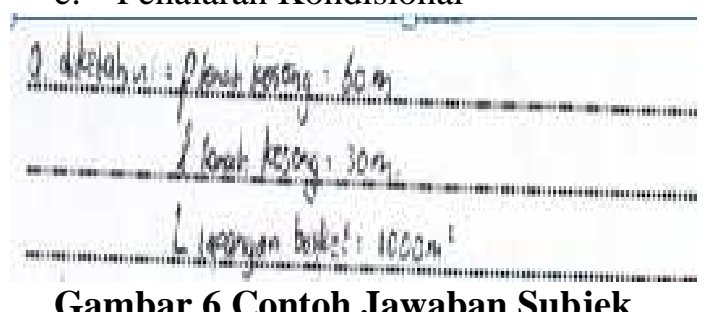

Gambar 6 Contoh Jawaban Subjek

Berdasarkan contoh jawaban subjek diatas maka dapat dilihat bahwa subjek mampu mengubah objek ke dalam representasi matematis melalui simbol menggunakan rumus, ini terlihat dari subjek dapat membuat permisalan dari luas lapangan yang dimisalkan dengan " $L$ ", lebar tanah kosong yang dimisalkan dengan " $l$ ", dan panjang tanah kosong yang dimisalkan dengan " $p$ ". Subjek dengan kemampuan awal tinggi, sedang, dan rendah mampu 
menggunakan penalaran kondisional dalam menyelesaikan masalah persamaan kuadrat dengan baik.

Berikut hasil temuan analisis tes tulis dan wawancara dapat dilihat pada Tabel 2

Tabel 2 Pengkodean Profil Penalaran Siswa Kelas X SMA dalam Menyelesaikan Masalah Persamaan Kuadrat ditinjau dari Kemampuan Awal Siswa

\begin{tabular}{cccccc}
\hline Subjek & \multicolumn{5}{c}{ Diskriptor Penalaran } \\
\hline$(1)$ & $(2)$ & $(3)$ & $(4)$ & $(5)$ & $(6)$ \\
\hline I & A1a & A2b & B1b & B2b & B3a \\
\hline II & A1a & A2b & B1c & B2b & B3a \\
\hline III & A1c & A2c & B1c & B2b & B3b \\
\hline IV & A1a & A2c & B1b & B2a & B3a \\
\hline V & A1a & A2c & B1c & B2b & B3b \\
\hline VI & A1a & A2c & B1c & B2b & B3a \\
\hline
\end{tabular}

Berdasarkan paparan data yang diperoleh dari penelitian didapatkan beberapa temuan adanya keberagaman penalaran setiap siswa saat menyelesaikan masalah dalam bentuk soal cerita materi persamaan kuadrat, yaitu siswa dengan kategori kemampuan awal tinggi dapat menyelesaikan masalah dengan baik, siswa dengan kategori kemampuan awal sedang dapat menyelesaikan masalah dengan cukup baik, sedangkan siswa dengan kategori kemampuan awal rendah masih kurang mampu menyelesaikan masalah dengan baik karena dalam mengevaluasi pemecahan masalah siswa dengan kategori kemampuan awal rendah cenderung menggunakan satu cara penyelesaian sehingga tidak dapat mengetahui kesamaan jawaban dengan cara yang berbeda dan kurang mampu dalam merencanakan langkah-langkah pemecahan masalah. Kemampuan penalaran siswa dengan kategori kemampuan awal rendah perlu mendapat perhatian. Oleh karena itu, kepada guru disarankan untuk menggunakan pembelajaran dengan pendekatan pemecahan masalah guna meningkatkan kemampuan penalaran siswa (Usniati, 2011:5).

Berdasarkan hasil temuan analisis tes tertulis dan wawancara pada Tabel 2 maka diperoleh penggunaan penalaran dalam menyelesaikan masalah persamaan kuadrat yaitu:

Polya (dalam Murtafiah, 2009: 104) menjelaskan bahwa dalam pemecahan masalah ada empat tahap:

a. Memahami masalah.

b. Merencanakan pemecahan.

c. Menyelesaikan masalah sesuai rencana langkah kedua.

d. Memeriksa kembali hasil yang didapat. Adapun penjelasannya sebagai berikut:

a. Memahami Masalah

Pada langkah ini, siswa harus dapat menentukan dengan teliti apa yang diketahui, apa yang ditanyakan serta bagaimana syarat (hubungan antara yang diketahui dengan yang ditanya). Siswa dituntut membaca soal dengan teliti sehingga dapat memahami maksud soal dengan baik. Pada tahap menentukan dan memahami masalah subjek melakukannya dengan cara menuliskan apa yang diketahui dan apa yang ditanyakan dari masalah tersebut. Seperti yang dikemukakan oleh Sudarman (dalam Marlina, 2010: 39) bahwa siswa dikatakan memahami masalah jika siswa mampu mengemukakan data yang diketahui dan yang ditanyakan dari masalah yang diberikan. Untuk menentukan yang diketahui dan yang ditanyakan maka subjek menggunakan penalaran analogi dan penalaran klasifikasi.

b. Merencanakan Pemecahan

Setelah memahami maksud soal dan dapat menetukan apa yang diketahui, ditanya, dan apa hubungan dari yang diketahui dan ditanyakan, maka untuk menjawab pertanyaan yang ada, siswa harus membuat rencana penyelesaian soal dengan mengumpulkan data-data yang ada, kemudian mengubah soal ke dalam kalimat matematika. Pada tahap merencanakan pemecahan masalah subjek melakukannya dengan cara membuat strategi yang akan dilakukan terhadap masalah yang diberikan. Seperti yang dikemukakan oleh Sudarman (dalam Marlina, 2010: 40) bahwa sejumlah strategi dapat membantu untuk merumuskan suatu 
pemecahan masalah. Untuk menentukan strategi pemecahan masalah maka subjek menggunakan penalaran silogisme kategorik dan penalaran kondisional.

c. Menyelesaikan Masalah Sesuai Rencana Langkah Kedua

Rencana yang telah tersusun dalam kalimat matematika dapat digunakan untuk menyelesaikan soal dengan menggunakan pengetahuan yang telah diperoleh sebelumnya. Pada tahap menyelesaikan masalah sesuai langkah kedua subjek melakukannya dengan cara melaksanakan rencana penyelesaian yang telah disusun untuk memecahkan masalah yang diberikan. Seperti yang dikemukakan oleh Sudarman (dalam Marlina, 2010: 4142) bahwa laksanakan rencana penyelesaian yang telah disusun dan jangan lupa mengecek setiap lagkah. Untuk melaksanakan rencana penyelesaian yang telah disusun untuk memecahkan masalah maka subjek menggunakan penalaran silogisme kategorik, penalaran silogisme linier, dan penalaran kondisional.

d. Memeriksa Kembali Hasil yang Didapat

Memeriksa kembali hasil yang didapat dilakukan untuk memastikan hasil pekerjaan dari tahap pertama sampai ketiga adalah benar, maka siswa harus melakukan pengecekan ulang. Pada tahap memeriksa kembali hasil yang didapat subjek melakukannya dengan cara meneliti kembali hasil yang telah diperoleh. Seperti yang dikemukakan oleh Sudarman (dalam Marlina, 2010: 42) bahwa memeriksa atau menelaah kembali langkah-langkah yang telah dilakukan dalam pemecahan masalah merupakan kegiatan yang sangat penting untuk meningkatkan kemampuan siswa dalam memecahkan masalah. Untuk meneliti kembali hasil yang telah diperoleh maka subjek melalukannya dengan menggunakan penalaran klasifikasi.

\section{KESIMPULAN DAN SARAN}

a. Kesimpulan

Berdasarkan hasil penelitian dan pembahasan yang diperoleh dapat diambil suatu kesimpulan profil penalaran siswa kelas X SMA dalam menyelesaikan masalah persamaan kuadrat ditinjau dari kemampuan awal siswa sebagai berikut.

1) Siswa dengan kemampuan awal tinggi memiliki kecenderungann menggunakan unsur-unsur penalaran induktif dan deduktif dengan baik. Siswa dapat memecahkan masalah persamaan kuadrat dalam bentuk soal cerita dengan baik dan tepat sesuai dengan langkah-langkah penyelesaian masalah.

2) Siswa dengan kemampuan awal sedang memiliki kecenderungan menggunakan unsur-unsur penalaran induktif dan deduktif dengan cukup baik. Pada umumnya siswa berkemampuan awal sedang dapat memecahkan masalah persamaan kuadrat dalam bentuk soal cerita dengan baik tetapi kurang mampu dalam menentukan cara lain untuk mencari jawaban dari yang ditanyakan.

3) Siswa dengan kemampuan awal rendah memiliki kecenderungan menggunakan unsur-unsur penalaran induktif dan deduktif dengan kurang baik. Pada umumnya siswa berkemampuan awal rendah kurang mampu memecahkan masalah persamaan kuadrat dalam bentuk soal cerita sesuai langkah-langkah pemecahan masalah dan tidak mampu dalam menentukan cara lain untuk mencari jawaban dari yang ditanyakan.

b. Saran

Berdasarkan hasil penelitian dan pembahasan, sebagaimana yang telah disimpulkan di atas, peneliti menyarankan agi peneliti lain yang berminat dapat mencoba untuk menggali lebih lanjut dari penelitian ini atau dapat melakukannya pada tingkat dan materi yang berbeda 
dengan sudut pandang peninjauan yang sama atau sudut pandang peninjauan yang lain mengenai profil penalaran siswa. Hasil penelitian ini juga dapat digunakan untuk melakukan penelitian pengembangan berdasarkan temuan-temuan yang diperoleh dalam penelitian.

\section{DAFTAR PUSTAKA}

Gunawan, Imam. 2014. Metode Penelitian Kualitatif. Jakarta: Bumi Aksara.

Harun, Lukman. (2010). Eksperimentasi Pembelajaran Matematika Dengan Pendekatan Contextual Teaching And Learning (CTL) ditinjau dari Kemampuan Awal Siswa Kelas VII SMP Negeri Kabupaten Sukoharjo. (Online),

(http://eprints.uns.ac.id/4569/1/170562 511201011541.pdf, Diunduh 21 Juni 2015).

Keraf, Gorys. 2010. Argumentasi dan Narasi. Jakarta : PT Gramedia.

King, Laura A. 2012. Psikologi Umum. Jakarta: Salemba Humanika.

Marlina, Leni. 2013. Penerapan Langkah Polya dalam Menyelesaikan Soal Cerita Keliling dan Luas Persegi Panjang. Jurnal Elektronik Pendidikan Matematika Tadulako (Online), Volume 01, Nomor 01, (http://jurnal.untad.ac.id/jurnal/index.p hp/JEPMT/article/view/1708/1125, Diunduh 27 Februari 2015).

Murtafiah, Wasilatul. 2009. Profil

Kemampuan Siswa Memecahkan Masalah Kontekstual Matematika di SMP Negeri 1 Madiun Jurnal Pendidikan MIPA (Volume 1, Nomor 2). Madiun: IKIP PGRI MADIUN.

Permana, Yanto dan Sumarmo, Utaru. 2007. Mengembangkan Kemampuan Penalaran dan Koneksi Matematik Siswa SMA Melalui Pembelajaran Berbasis Masalah. Jurnal Educationist (Online), Volume 01, Nomor 02, (http://file.upi.edu/Direktori/JURNA L/EDUCATIONIST/Vol_I_No._2Juli2007/6_Yanto_Permana_Layout2 rev.pdf, Diunduh 11 Maret 2015).

Purwandari, Huriawati Farida, dan Andista. 2012. Efektifitas Inquiry
Terbimbing dan Inquiry Bebas Termodifikasi Melalui Eksperimen Terhadap Hasil Belajar Fisika Ditinjau dari Kemampuan Awal, Kreatifitas, Kemampuan Berpikir Abstrak Siswa Kelas X SMA Negeri 6 Kota Madiun Tahun Ajaran 2010/2011. Jurnal Pendidikan (Volume 18, Nomor 1). Madiun: IKIP PGRI MADIUN.

Uno, Hamzah R dan Umar, Masri Kudrat. 2009. Mengelola Kecerdasan dalam Pembelajaran. Jakarta: PT. Bumi Aksara.

Usniati, Mia. 2011. Meningkatkan Kemampuan Penalaran Matematika melalui Pendekatan Pemecahan Masalah. (Online),

(http://repository.uinjkt.ac.id/dspace/ bitstream/123456789/1406/1/100747 -MIA\%20USNIATI-FITK.pdf, Diunduh 11 Maret 2015).

Winarni, Endang Setyo dan Harmini, Sri. 2011. Matematika untuk PGSD. Bandung: PT Remaja Rosdakarya Offset. 